\title{
Millennials in Efforts to Build Anti-Corruption Behavior
}

\author{
Dyah Lituhayu $^{1}$, Sri Suwitri ${ }^{2}$, Y. Warella ${ }^{3}$, Ida Hayu Dwimawanti ${ }^{4}$ \\ \{lialituhayu@gmail.com ${ }^{1}$ \} \\ Universitas Diponegoro, Indonesia ${ }^{1,2}$
}

\begin{abstract}
The research purpose of describe how millennial will be built anti-corruption behavior in Kudus Regent. Kudus head regional for the second time was arrested by KPK for corruption as a form of bureaucratic disease that has hit almost all over the world, as well as it is happening in the bureaucracy at Indonesia, thus disrupting of the bureaucracy in providing public services. Various attempts have been made by the government to prevent corrupt behavior, either by making regulations or forming a commission to deal with the problem of corruption, but this has not been able to overcome the rampant or high number of corruptions. This study uses a qualitative approach, to describe how to build anti-corruption behavior from a young generation, which will later become the next generation in the wheels of government. The results show according millennial that building anti-corruption behavior must understand the causes of corruption behavior and the culture of the community. The occurrence of corruption behavior is partly due to the structure in the bureaucracy, while efforts to form cannot be separated from the culture of the community as specially commonly of 'money politic' as ones of causes corruption at bureaucracy. Therefore, the model for efforts of anti-corruption behavior must be carried out using are the behaviorism approach and the structural/institutional approach together.
\end{abstract}

Keywords: Millenials, Corruption, Bureaucracy, Behavior

\section{Introduction}

Corruption is a disease and an enemy of governance and bureaucracy. In Indonesia, it seems that corruption is an inherent character in the bureaucracy, and various efforts have been made by the government by creating a commission to overcome this corruption issue. However, the existence of regulations and commissions made by the government has not been able to overcome the rampant or high number of corruptions. This is shown by the large number of government officials in the Indonesian bureaucracy who did the corruption.

Many previous studies found that there were cases of transfer or dismissal of officials in the local government bureaucracy who were moved or demoted without clear reasons. Research conducted by La Ode [1] found that in Muna District the regional head holds full authority in every decision making, both within the party and in government administration. The administration of government in Muna Regency is inseparable from the political interests shown by the bureaucratic positions that come from officials who are loyal to political parties and officials who are committed to party interests. President Joko Widodo even reiterated his commitment to efforts to eradicate corruption in Indonesia. He considered that until now efforts to eradicate and prevent corruption have not been successful yet, because there are still many state officials who have been arrested for being involved in corruption case. According 
to data reported to Mr. Jokowi (the President of Indonesia Republic), there were 370 state officials who had been jailed for corruption cases. The details were 122 members of the House of Representative and Regional House of Representative, 25 ministers or heads of departments, 4 ambassadors, 7 commissioners, 17 governors, 51 regents and mayors, 130 from echelon I to echelon III officials, and 14 judges. "The number of state officials who had been jailed was not something to be proud of. In my opinion, the fewer are jailed, it means we are increasingly successful in preventing and eradicating corruption", said Jokowi in his statement at the opening of the 2016 National Corruption Eradication Conference at Balai Kartini Building, Jakarta, Thursday (1/12/2016).

The phenomenon of major city with political interests and corrupt behavior occurs in the city of Tegal because Law Number 5 of 2014 concerning State Civil Servants allows regional head to unilaterally appoint and transfer bureaucratic apparatus in the regions. The authority of regional heads in recruiting employees and placing officials in their regions can reduce the degree of professionalism of the bureaucracy in the regions. Many strategic positions or positions in the government structure are not filled with professional civil servants as a well as is attend of non-professional servants, who's a closely of major city.

Therefore, in the bureaucracy, it is very possible for corrupt behavior to occur, even the corruption case committed by the regional head of Kudus district is quite interesting of the public's attention, considering that the regional head has been caught in a corruption case for the second time.

The higher of corruption cases that occur within the bureaucracy is certainly a challenge for the younger generation who will later become the next generation in managing the bureaucracy at Indonesia. Therefore, it is necessary to see how the younger generation builds anti-corruption behavior within the Indonesian government.

\section{Method}

The research objectives to describe how the millennials seeks to build anti-corruption behavior. Focus this research is young generation of Karang Taruna at Kudus regent. Method used is qualitative using in-depth interviewing techniques and FGD. This research was taken place in Kudus Regent.

\section{Results and Discussion}

The research on that related to combat corruption has been conducted by Marquette and Peiffer, paper presented at the ECPR Joint Sessions of Workshops, University of Warsaw 29 March-2 April 2015, the intricacies of accountability: horizontal, vertical and diagonal mechanisms to combat corruption [2]. This research results that in order to fight corruption we must first understand the function of corruption itself by using action theory and group agency theory. Departing from this research, in an effort to fight corruption, it is necessary to form anti-corruption behavior which is a form of anticipation to prevent corrupt behavior. Other research results that are also related to society have also been carried out by Melgar, Rossi and Smith [3], corruption and corruption perception can be considered as cultural phenomena. 
Efforts to form anti-corruption behavior cannot be separated from the causes of corruption. And the corruption cases that occurred in Kudus district were caused by the monopoly of power as well as the authority possessed by regional heads in placing ASN positions in the bureaucratic status. This condition is in line with the theory put forward by Klitgaard [4] which states that the causative factors define corruption in the following formula: $\mathrm{C}=\mathrm{M}+\mathrm{D}-\mathrm{A}$. This means that corruption occurs due to monopoly (M) and authority $(\mathrm{D}=$ discretionary power) and lack of accountability $(\mathrm{A})$. In other words, the greater the monopoly and authority a person has, but the less accountability that person has, the more likely he is to commit corruption. Field findings show that the corruption committed by the regent of Kudus is the placement of structural positions for civil servants. Corruption cases for regional heads by selling office prices have often occurred in government bureaucracy in Indonesia, such as the case of the Regent of Klaten with transactional positions in the Education Office with corruption values. IDR 12,877 billion with a prison sentence of 11 years (Bali post, 10 May 2019).

This transactional model of position corruption behavior is in accordance with historian John Ivo E in Priyono [5] who said that the notion of corruption as a violation of the rules of political and public office for personal purposes is indeed the most sensible definition of the meaning of corruption. always attached to the body of the bureaucracy, and is a challenge for the current generation of millennial

The results of the research findings are generation of millennial did not reject the real condition of the bureaucracy is corrupting. Currently head regent of Kudus has been a hold for a second time of corrupt. The former corruptor has been reaching as major, is depend on society. How millennial though that is former corruptor it isn't problem. According them, forgiving is reason for support former corruptor. The millennial has the principle that people must forgive someone.

Empirical findings, that the second time corruption case of major is used power, especially for promotion of officials. The power use to commit corruption has also been written by Wang and Sun [6]. Absolute power leads to absolute corruption? Impact of power on corruption depending on the concepts of power one holds School of Psychology, Beijing Normal University, Beijing, China, Institute of Psychology Power has long been associated with the stigma of corruption. Three studies show that different concepts of power have different implications for corruption behavior and perceptions. The concept of personalized power is concerned with the strength to pursue self-centered goals for one's convenience, whereas the concept of socialized power is concerned with the strength to pursue otherfocused goals to benefit and help others. Bernandez [7] has also studied the model of governance and corruption. Determinants of political corruption a conceptual framework that corruption can be seen as the power use by public officials for individual purposes.

According millennial that efforts to build anti-corruption must be balanced between individual wishes and supported by regulations and society.

Public support is also considered important according to the millennial, because the cultural conditions of our society receiving money politic in regional head elections are considered normal and mandatory for candidates. This is where lessons are needed to be given to society, including the younger generation, especially those who are involved in the process of selecting public officials for the first time, which are full of political interests.

Discussion on the prevention of corruption behavior is related to the personal control of each individual. Aspects or phenomena of corruption behavior illustrate that personality, situational and organizational structure are the reasons for someone to do deviant behavior. 
The conditions driving this behavior are corrupt behavior related to power; monopoly and lack of accountability.

The research finding that millennial think, that the corruption has been occurs is as if it is systemic. In the sense, society has been supporting this behavior. Look as systemic are organized and difficult to avoid, because it has become a routine and habitual process in various aspects of daily life, whether consciously or not. As is happening, there is money politics in the regional elections that is considered a normal thing: "Corruption has become part of the existing system", so it is quite difficult to determine the beginning of the anticipation of corruption eradication, if it is done with a psychological approach especially behaviorism.

The efforts to form anti-corruption behavior can be done by approaching behaviorism and institutionalism. These two approaches in shaping anti-corruption behavior still refer to these three things, so two approaches will be used, namely behavioralist and structuralism/institutionalism as below.

The strategy for making changes can be initiated with institutional changes or restructuring of the government bureaucracy. Because bureaucratic institutions are a form of order that contains structure and culture. While the structure focuses on the structure of an order, and culture contains values, systems, and habits carried out by the perpetrators. Therefore, two approaches need to be used to form anti-corruption behavior, namely behaviorism and structuralism or institutionalism.

\section{References}

[1] L. Ida, "Election and political evil ambition in Indonesia's reformasi era," Int. J. Polit. Good Gov., vol. 5, no. 5.4, pp. 1-24, 2014.

[2] H. Marquette and C. Peiffer, "Collective action and systemic corruption," in ECPR Joint Sessions of Workshops, University of Warsaw, 2015, vol. 29.

[3] N. Melgar, M. Rossi, and T. W. Smith, "The perception of corruption," Int. J. Public Opin. Res., vol. 22, no. 1, pp. 120-131, 2010.

[4] R. Klitgaard, “Membasmi Korupsi,” Jakarta Yayasan Obor Indones., 2001.

[5] B. H. Priyono, Korupsi: Melacak Arti, Menyimak Implikasi. Gramedia Pustaka Utama, 2018.

[6] F. Wang and X. Sun, "Absolute power leads to absolute corruption? Impact of power on corruption depending on the concepts of power one holds," Eur. J. Soc. Psychol., vol. 46, no. 1, pp. 77-89, 2016.

[7] P. B. Bernaldez, "Determinants of political corruption: A conceptual framework," Int. J. Graft Corrupt. Res., vol. 1, no. 1, 2014. 